\title{
Prevalence of atopic dermatitis in infants during the first six months of life: authors' observations
}

\author{
Barbara Kamer ${ }^{12}$, Renata Pasowska², Elżbieta Dółka², Agnieszka Blomberg1, Helena Rotsztejn ${ }^{3}$ \\ 1Polish Mother's Memorial Hospital - Research Institute, Lodz, Poland \\ Head of Department: Prof. Przemysław Oszukowski MD, PhD \\ 22nd Department of Paediatrics and Allergology, Polish Mother's Memorial Hospital - Research Institute, Lodz, Poland \\ Head of Department: Prof. Barbara Kamer MD, PhD \\ 3Department of Cosmetology, Medical University of Lodz, Lodz, Poland \\ Head of Department: Prof. Ryszard Glinka MD, PhD
}

Postep Derm Alergol 2013; XXX, 5: 277-281

DOI: $10.5114 /$ pdia.2013.38355

\begin{abstract}
Introduction: Atopic dermatitis (AD) is a frequent chronic skin disease in infants. It creates great difficulties, both diagnostic and therapeutic.

Aim: To assess the prevalence of atopic dermatitis in infants during the first 6 months of life.

Material and methods: The analysis comprised 2256 children at the age of not more than 6 months, treated at the $2^{\text {nd }}$ Department of Paediatrics and Allergology of the Polish Mother's Memorial Hospital in Lodz, Poland, during seven years. Out of all the patients, children with cutaneous changes were isolated, and the location, type and aetiology of changes were assessed.

Results: Dermal changes were diagnosed in 471 children, including 391 (17.3\% of all the patients) with atopic dermatitis. Out of the children with AD, IgE-dependent allergy was identified in $39.9 \%$. Cow's milk protein was the most frequent sensitising allergen. In $71.6 \%$ of the infants, cutaneous changes were disseminated and involved at least two areas of the body. All of them were strongly itching. An applied elimination diet, together with anti-allergic medications in some of the children, provided a clear clinical improvement.

Conclusions: Performed studies demonstrated the prevalence of atopic dermatitis in $17.3 \%$ of examined children. The changes in children with AD were disseminated, what was confirmed already at the infantile age. The obtained clinical improvement after the applied therapy indicates a relationship between the observed symptoms and allergic disease.
\end{abstract}

Key words: atopic dermatitis, prevalence, infants.

\section{Introduction}

Atopic dermatitis (AD) is a chronic and recurrent inflammatory skin disease [1-3]. The medical condition was described for the first time by Wise and Sulzberger in 1933 [4]. It appears from literature data that, in children with $A D$, the first symptoms of the disease occur up to 6 months and 5 years of life in $45 \%$ and $80-90 \%$ of the children, respectively [5-10]. In general, the incidence of atopic dermatitis is assessed at $15-20 \%$ of the human population. Many authors emphasise that the incidence has been growing systematically [1, 3, 6, 10-18]. Atopic dermatitis is a medical condition of multifactorial and still not completely known aetiology and pathogenesis [1, 19-22], involving a large contribution of genet- ic and environmental factors. Among the genetic causes, a filaggrin gene defect is a proven risk factor for $A D$ as it probably leads to lesions in the epidermal barrier [23, 24]. In children with an ectodermal skin defect, disturbed metabolism of epidermal lipids is observed. These children present with a decreased production of ceramides in the corneal layer of the epidermis and an increased level of $\boldsymbol{\gamma}$-linolenic and arachidic acid in blood serum. All this leads to an increased skin water loss and excessive skin dryness. These changes are thus responsible for cutaneous hypersensitivity to a number of environmental factors $[25,26]$. Allergic diseases in the familial history are also claimed to be important causative factors $[2,13,27,28]$ and neurovegetative disor-

Address for correspondence: Prof. Barbara Kamer MD, PhD, 2nd Department of Pediatrics and Allergology, Polish Mother's Memorial Hospital - Research Institute, 281/289 Rzgowska St, Lodz 93-338, Poland, phone: +48 422712091 , fax: +48 42 271 13 86,

e-mail: bkamer@wp.pl

Received: 23.11.2012, accepted: 22.05.2013. 
ders (the relationship between the inflammatory skin condition and the nervous system e.g. in the mechanism of neurogenic inflammation) $[2,13,19]$, while environmental factors include the climate, air contamination, alimentary, inhaled and infective: viral, bacterial and fungal ones [1, 2, $7,11,21,29,30]$. Bacteria, e.g. Staphylococcus aureus and Candida may enhance atopic dermatitis by skin damage, production of superantigens and increased production of immunoglobulin E. Similarly, allergens influence the production of IgE and increase the activity of Th2 lymphocytes. Disturbances of the immune system, including humoral and cellular immunity, as well as psychological factors and stress are also important contributory factors [1, 11, 21, 27, 28]. Atopic dermatitis is clinically manifested by extensive cutaneous changes, accompanied by persistent itch [2, 7, 8, 29, 31]. All these changes usually demonstrate a fairly typical localisation [2, 7, 31], however, at the infantile age, they may be disseminated and less characteristic, without the typical predilection for definite body regions, which is found at a later age [10,32]. The diagnosis of atopic dermatitis is a rather difficult task, still based on major and minor identification criteria, as proposed by Hanifin and Rajka [33]. Many authors emphasise the fact that, at least in small children, atopic dermatitis is often concomitant with allergic symptoms from other systems [2, 22, 32], especially from the gastric [34] and respiratory tract [2, 8]. This concomitance of symptoms from other systems is supported by their anatomical-functional immaturity as well as immaturity of the immune system [11, 21, 29].

\section{Aim}

The aim of the study was to assess the prevalence of $A D$ in infants during the first 6 months of life.

\section{Material and methods}

A retrospective analysis comprised 2256 children in the first 6 months of life, including 1359 (60.2\%) boys and 897 (39.8\%) girls, treated at the $2^{\text {nd }}$ Department of Paediatrics and Allergology of the Polish Mother's Memorial Hospital in Lodz, Poland in 2003-2009.

In order to isolate children with cutaneous changes, a detailed medical history was obtained, following a questionnaire, designed by the authors themselves. The questionnaire enquired, among others, about the familial history of allergic diseases, type of nutrition, occurrence of allergy clinical symptoms as well as clinical examination (i.e. location and kind of skin lesions). The diagnosis of atopic dermatitis was based on the presence of clinical symptoms consistent with Hanifin and Rajka criteria [33, 34]. Allergy, as a cause of cutaneous changes, was confirmed by positive results of an open food challenge test and results of allergic-immunological assays (total lgE and allergen-specific IgE antibodies in blood serum). Immunoglobulin E concentrations were assayed by the immunoenzymatic method with a Fluoro-Fast device of the $3 \mathrm{M}$ Diagnostic Systems. Following the manufacturer's recommendations, all the values above the mean concentration level of \pm 2 SD, i.e.17.2 $\mathrm{IU} / \mathrm{ml}$ were regarded as increased concentrations. Blood serum concentrations of allergen-specific lgE antibodies against selected alimentary allergens, including cow milk proteins, egg white and yolk, carrot and soy, as well as against inhaled allergens, i.e., mites and moulds, were assayed by the immunochemical method with IgE FAST Plus kits of 3M "Diagnostic System". All the concentrations of class $\geq 2$ of the 4 -stage classification of atopic disease were regarded as increased values [35]. In all the children with a diagnosed food allergy, a harmful food eliminating diet was introduced plus anti-allergic agents, the latter in children with food and inhaled allergy. Re-examination was carried out after $2-3$ weeks of using the diet.

\section{Statistical analysis}

The obtained results were subject to statistical analysis, calculating the basic statistical parameters. The comparisons between groups were assessed with the $\chi^{2}$ test. Pearson's coefficient and the equation regression coefficient were calculated to determine relationships among the studied features.

\section{Results}

The analysis of the obtained results revealed 471 children with various cutaneous changes, including 391 with atopic dermatitis and 80 with other different conditions - most frequently (43 children - 53.7\%) with seborrhoeic dermatitis. Parvovirus B infections was more rarely observed (18 children - 22.5\%), as well as viral infection (13 children $-16.2 \%)$, psoriasis in two children (2.5\%) and other conditions (scabies, bacterial dermatitis, drug reaction and fungal dermatitis) in 4 (5\%) children.

Atopic dermatitis was found in $83.0 \%$ of the children with cutaneous changes, i.e. in $17.3 \%$ of all the examined children. The group of children with diagnosed AD included 234 (59.9\%) boys and 157 (40.1\%) girls, with highly prevailing infants in the first quarter of life (61.4\%). An analysis of atopic dermatitis prevalence in the children over the subsequent years of hospitalization revealed its level to be varied between $15.1 \%$ and $20.4 \%$. It should be emphasised that the confirmed differences were lower than 10\% and thus did not attain the level of statistical significance (Figure 1). However, the calculated coefficient of regression $(R)$ demonstrated a rising tendency - about 0.4\% per year (Figure 2).

An analysis of the nutrition type in children with $A D$ demonstrated a higher number - 208 (53.2\%) of formulafed infants (on bottle from birth). Among the remaining children, 121 (30.9\%) were exclusively breast-fed, while 62 (15.9\%) received mother's milk and formula milk.

It was also found out that 192 (49.1\%) children with AD were genetically loaded in their families. Allergic disease 
A

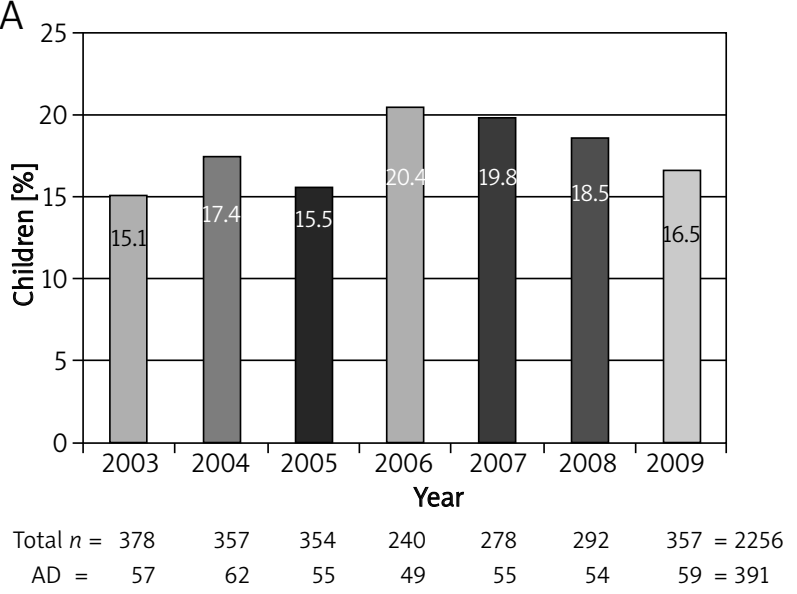

B

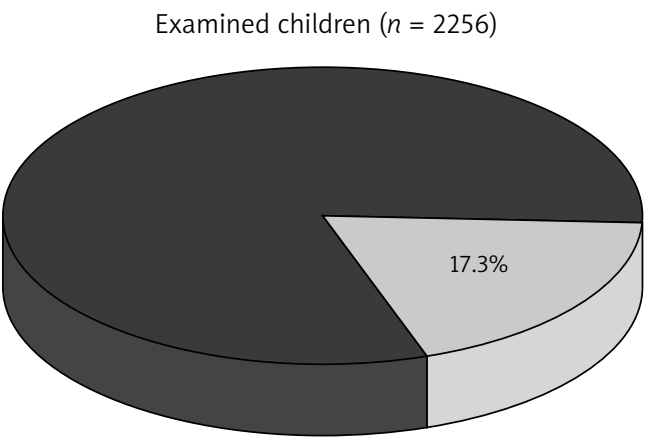

$\square$ With $\operatorname{AD}(n=391)$

$\chi^{2} n=5.3834 \quad p=0.4957$

Pearson's correlation $=0.0488$ (difference $<10 \%$ is not statistically significant)

Figure 1. Frequency of atopic dermatitis in examined children in particular years of hospitalization

was most frequent in mothers (35.4\%), then in fathers (25.5\%), siblings (24.5\%) and grandparents (18.7\%). An analysis of the allergy type in children with AD demonstrated IgEdependent allergy in 156 (39.9\%) and allergy from other (than IgE-dependent) mechanism in the remaining 235 children. Among the examined children with IgE-dependent allergy, increased concentrations of immunoglobulin $E$ were found in $86(55.1 \%)$ of them. An evaluation of the concentration of allergen-specific antibodies indicated their increase in 161 tests with regard to food allergens, including 139 (86.3\%) against cow milk proteins, 7 (4.4\%) against egg white and 5 (3.1\%) against egg yolk, 6 (3.7\%) against carrot and 4 (2.5\%) against soy. Increased concentrations of aslgE were also found in 13 tests for antibodies against inhaled allergens, including 9 (5.8\%) against house dust mites and 4 (2.6\%) against moulds. It was also observed that the highest prevalence rates, namely $90.1 \%$ among the concentrations of allergen-specific antibodies against food allergens and 100\% among those against inhaled allergens, were for those in class 2, following the 4-stage classification of atopic disease (Table 1).

An evaluation of the observed cutaneous changes revealed that only in 111 children, the changes were limited to one body region and localised on the face skin. They were observed in 84 children in the first quarter of life and in 27 children in the second one. In the remaining 280 (71.6\%) children, the changes were disseminated and simultaneously concerned, at least, two or more body regions (Table 2). The changes formed papulo-erythematous and desquamating, severely itching foci. It was also observed that in more than a half of the patients, i.e. in 252 (64.5\%) children, cutaneous changes were accompanied by symptoms from other organs, including 140 (35.8\%) from the gastric tract with 69 (49.3\%) having intestinal colic, 9 (6.4\%) - constipation, 47 (33.6\%) - vomiting, 15 (10.7\%) - chronic diarrhoea [32], and $112(28.6 \%)$ from the respiratory tract. In the children with symptoms from the respiratory tract, 26 (23.2\%) present-

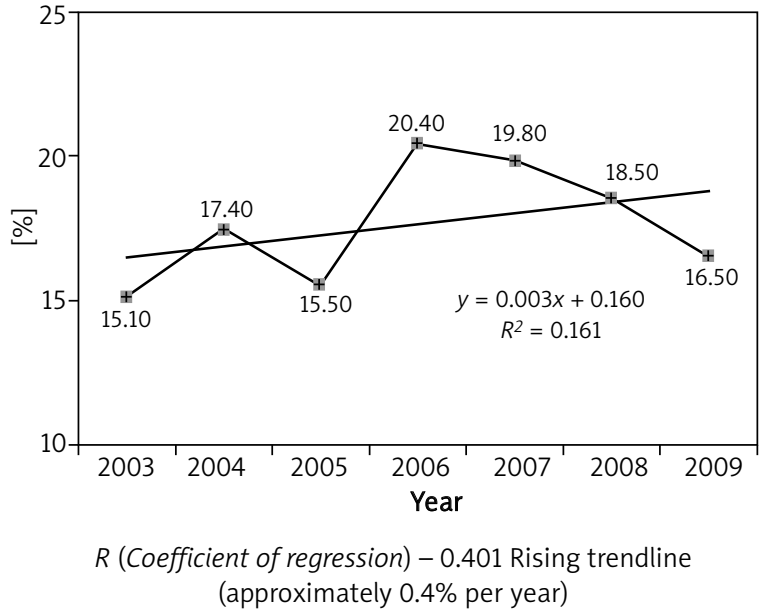

Figure 2. Percentage of children with $A D$ and year of hospitalization

ed with coryza, 8 (7.1\%) with otitis and 78 (69.6\%) infants with recurring infections of the lower airways.

In each child with food allergy, a harmful food-eliminating diet was applied with an additional anti-allergic therapy, administered in some, especially in those sensitised to inhaled allergens. Re-examination after 2-3 weeks of the therapy revealed clinical improvement.

\section{Discussion}

Atopic dermatitis is a serious clinical, social and economic problem [10, 21]. Many authors emphasise the influence of the disease on the quality of life of the affected child and its family, for it has been demonstrated that as many as $80 \%$ of patients with AD present with sleep disorders and/or periodical episodes of irritation and anxiety $[21,36]$. According to literature data, symptoms of the disease occur early, already in the first years of life 
Table 1. Analysis of elevated levels/class/slgE in examined children with IgE-dependent allergy

\begin{tabular}{|c|c|c|c|c|c|c|c|c|}
\hline \multirow[t]{3}{*}{ Allergens } & \multicolumn{6}{|c|}{ Levels/class/slgE } & & \\
\hline & \multicolumn{2}{|c|}{$\begin{array}{c}2 \\
0.76-2.99 \mathrm{IU} / \mathrm{ml}\end{array}$} & \multicolumn{2}{|c|}{$\begin{array}{c}3 \\
3.0-17.5 \mathrm{IU} / \mathrm{ml}\end{array}$} & \multicolumn{2}{|c|}{$\begin{array}{l}4 \text { and over } \\
>17.5 \mathrm{IU} / \mathrm{ml}\end{array}$} & \multicolumn{2}{|c|}{ Total } \\
\hline & $n$ & $\%$ & $n$ & $\%$ & $n$ & $\%$ & $n$ & $\%$ \\
\hline \multicolumn{9}{|l|}{ Food } \\
\hline Cow's milk protein & 129 & 92.8 & 8 & 5.8 & 2 & 1.4 & 139 & 86.3 \\
\hline Egg white & 4 & 57.1 & 3 & 42.9 & 0 & 0.0 & 7 & 4.4 \\
\hline Egg yolk & 3 & 60.0 & 2 & 40.0 & 0 & 0.0 & 5 & 3.1 \\
\hline Carrot & 6 & 100.0 & 0 & 0.0 & 0 & 0.0 & 6 & 3.7 \\
\hline Soy & 3 & 75.0 & 1 & 25.0 & 0 & 0.0 & 4 & 2.5 \\
\hline Total & 145 & 90.1 & 14 & 8.6 & 2 & 1.3 & 161 & 100.0 \\
\hline \multicolumn{9}{|l|}{ Inhaled } \\
\hline House dust mite & 9 & 100.0 & 0 & 0.0 & 0 & 0.0 & 9 & 69.2 \\
\hline Moulds & 4 & 100.0 & 0 & 0.0 & 0 & 0.0 & 4 & 30.8 \\
\hline Total & 13 & 100.0 & 0 & 0.0 & 0 & 0.0 & 13 & 100.00 \\
\hline
\end{tabular}

Table 2. Analysis of location of skin lesions in infants with atopic dermatitis

\begin{tabular}{lcc}
\hline Location of skin lesions & \multicolumn{2}{c}{ Examined infants $(n=391)$} \\
\cline { 2 - 3 } & $n$ & $\%$ \\
\hline Isolated & 111 & 28.4 \\
\hline Face & 84 & 21.5 \\
\hline Trunk & 15 & 3.8 \\
\hline Limbs & 12 & 3.1 \\
\hline Disseminated & 280 & 71.6 \\
\hline $\begin{array}{l}\text { Face } \\
\text { Trunk }\end{array}$ & 109 & 27.9 \\
\hline $\begin{array}{l}\text { Face } \\
\text { Limbs }\end{array}$ & 22 & 5.6 \\
\hline $\begin{array}{l}\text { Trunk } \\
\text { Limbs }\end{array}$ & 24 & 6.1 \\
\hline $\begin{array}{l}\text { Face } \\
\text { Trunk } \\
\text { Limbs }\end{array}$ & 125 & 32.0 \\
\hline
\end{tabular}

[5, 7-9]. Similarly, the results of our studies demonstrated a high prevalence (17.3\%) of atopic dermatitis in the examined children during the first half-year of their life, the prevalence being similar to that reported in literature [7, 13-18]. Prevalence variations, observed in particular years of the observation period, are small and similar to those noted in other countries. The results, reported by other authors, demonstrate differentiated prevalence rates of $A D$ in various countries, for example, $17.2 \%$ in the USA, $15.6 \%$ in Europe and $24 \%$ in Japan [quoted from 7]. The results of the ISAAC study (International Study of Asthma and Allergies in Childhood) revealed a relationship between the disease frequency and the child's age at the following levels: $<2-16 \%$ in 6-7-year-old children and $<17 \%$ in 13-14-year-old children. It should also be noted that the results of performed studies did not show any relationship be-tween the prevalence of $A D$ and the sex of the examined patients [1], while among our children, boys significantly prevailed, what could have been associated with the prevalence of male sex in all the children, hospitalized at our Department during that period.

Atopy plays a significant role in the development of atopic dermatitis, thus big importance is attributed to genetic factors, including the presence of allergic diseases in the family [1, 2, 4, 21, 27]. Among our children, almost a half presented a positive familial history towards allergy. Similarly, a number of authors emphasise the role of food allergy in AD development, which is present in $25-50 \%$ of AD-affected children, the cow milk proteins being the most frequent sensitising allergen [2, 4, 8, 9]. Food allergy was a frequent cause of observed changes in our patients and increased concentrations of aslgE against cow milk allergens were found in as many as $89.1 \%$ of children with IgE-dependent allergy.

It should be noted that the localisation of cutaneous changes differs depending on the age of AD-affected children $[2,4,10]$. However, some authors emphasise that disseminated changes, involving more than one body region, may occur already in infants $[1,34,36]$. Our observations are similar as disseminated changes were found in the majority of our children.

The development and exacerbation of atopic dermatitis can be supported by the introduction of milk formula $[8,37]$. Most of our children with AD were from birth either on bottle or mixed diet (mother's milk + milk formula). 
It is well known that an elimination of the harmful allergen is the most effective therapeutic step in allergic children $[34,38]$. It may then explain the clinical improvement, observed after the introduced elimination diet, what prompted us to attribute the diagnosed cutaneous changes to the underlying allergy (a cause-effect relationship).

\section{Conclusions}

The performed studies demonstrated the prevalence of atopic dermatitis in $17.3 \%$ of examined patients. Children with AD present with disseminated cutaneous changes already at the infantile age. The obtained, post-therapeutic clinical improvement indicates a cause-effect relationship between allergic disease and observed cutaneous symptoms.

\section{References}

1. Knoell KA, Greer K. Atopic dermatitis. Pediatr Rev 1999; 20 : 46-51.

2. Gliński W, Kruszewski J, Silny W, et al. Postępowanie diagnostyczno-profilaktyczno-lecznicze w atopowym zapaleniu skóry. Konsensus grupy roboczej specjalistów krajowych ds. dermatologii i wenerologii oraz alergologii. Pol Merk Lek 2004; 17 (Suppl. 3): 3-15.

3. Böhme M, Lannerö E, Wickman M, et al. Atopic dermatitis and concomitant disease patterns in children up to two years of age. Acta Derm Venerol 2002; 82: 98-103.

4. Adamek-Guzik T, Guzik T, Czerniawska-Mysik G, Pryjma J. Znaczenie obniżonej odporności na infekcje w patogenezie atopowego zapalenia skóry: rola Staphylococcus aureus. Alergia Astma Immunol 2001; 6: 169-79.

5. Małolepszy J, Liebhart J, Wojtyniak B, et al. Występowanie chorób alergicznych w Polsce. Alergia Astma Immunol 2000; 5: 163-9.

6. Krakowski AC, Eichenfield LF, Dohil MA. Management of atopic dermatitis in the pediatric population. Pediatrics 2008; 122: 812-24.

7. Wanat-Krzak M, Doniec Z, Kurzawa R. Atopowe zapalenie skóry u dzieci - aktualne zalecenia diagnostyczno-lecznicze. Standardy Medyczne 2003; 5 (Suppl.): 58-65.

8. Majewski S. Atopowe zapalenie skóry: „astma skórna” czy tylko świąd? Alergia 2000; 3: 24-9.

9. Paller AS, McAlister RO, Doyle JJ, Jackson A. Perceptions of physicians and pediatric patients about atopic dermatitis, its impact, and its treatment. Clin Pediatr (Phila) 2002; 41: 323-32.

10. Horii KA, Simon SD, Liu DY, Sharma V. Atopic dermatitis in children in the United States, 1997-2004: visit trends, patient and provider characteristics, and prescribing patterns. Pediatrics 2007; 120: 527-34.

11. Fleischer AB Jr. Atopic dermatitis. Perspectives on a manageable disease. Postgrad Med 1999; 106: 49-55.

12. Kurz H, Riedler J. An increase in allergic disease in childhoodcurrent hypotheses and possible prevention. Wien Med Wochenschr 2003; 153: 50-8.

13. Peroni DG, Piacentini GL, Bodini A, et al. Prevalence and risk factors for atopic dermatitis in preschool children. Br J Dermatol 2008: 158: 539-43.

14. Larsen FS, Hanifin JM. Epidemiology of atopic dermatitis. Immunol Allergy Clin N Am 2002; 22: 1-25.

15. Ibáñez MD, Garde JM. Allergy in patients under fourteen years of age in Alergológica 2005. J Investig Allergol Clin Immunol 2009; 19 (Suppl. 2): 61-8.
16. Kuhnyar A, Egyud K, Szabo I, et al. Prevalence of atopic dermatitis among children under 19 in an East-Hungarian agricultural county. Clin Dev Immunol 2006; 13: 395-9.

17. Kvenshagen B, Jacobsen M, Halvorsen R. Atopic dermatitis in premature and term children. Arch Dis Child 2009; 94 : 202-5.

18. Nieto A, Mazon A, Martin-Mateos MA, et al. Pediatric allergy and immunology in Spain. Pediatr Allergy Immunol 2011; 22: $742-50$.

19. Chan LS, Atopic dermatitis in 2008. Curr Dir Autoimmun 2008; 10: 76-118.

20. Kruszewski J. Genetyczne uwarunkowania atopii. Postep Derm Alergol 2003; 2: 58-64.

21. Silny W, Czarnecka-Operacz M, Gliński W, et al. Atopowe zapalenie skóry - współczesne poglądy na patomechanizm oraz metody postępowania diagnostyczno-leczniczego. Stanowisko grupy specjalistów Polskiego Towarzystwa Dermatologicznego. Postep Derm Alergol 2010; 27: 365-83.

22. Żukiewicz-Sobczak W, Krasowska E, Zwoliński J, et al. Allergic diseases - current state of knowledge. Postep Derm Alergol 2012; 29: 451-5.

23. Ponińska J, Samoliński B, Tomaszewska A, et al. Filaggrin gene defects are independent risk factors for atopic asthma in a Polish population: a study in ECAP kohort. PLoS One 2011; 6: 16933.

24. Suh KY. Food allergy and atopic dermatitis: separating fact from fiction. Semin Cutan Med Surg 2010; 29: 72-8.

25. Chamlin SL, Kao J, Frieden IJ, et al. Ceramide-dominant barrier repair lipids alleviate childhood atopic dermatitis: changes in barrier function provide a sensitive indicator of disease activity. J Am Acad Dermatol 2002; 47: 198-208.

26. Yen $\mathrm{CH}$, Dai YS, Yang YH, et al. Linoleic acid metabolite levels and transepidermal water loss in children with atopic dermatitis. Ann Allergy Asthma Immunol 2008; 100: 66-73.

27. Kleniewska D. Atopic dermatitis. Nowa Klinika 1994; 4: 37-40.

28. Ou LS, Huang JL. Cellular aspects of atopic dermatitis. Clin Rev Allergy Immunol 2007; 33: 191-8.

29. Szałek E, Kaczmarek Z, Grześkowiak E, Głęboka A. Znaczenie probiotyków w farmakoterapii AZS w pediatrii. Farmacja Współczesna 2009; 2: 192-6.

30. Pastuszka M, Matych M, Kaszuba A, et al. Microorganisms in the etiopathogenesis of atopic dermatitis. Postep Derm Alergol 2012; 29: 215-21.

31. Czerwionka-Szaflarska M, Adamska I, Świątek K. Rola alergii pokarmowej w atopowym zapaleniu skóry: metody leczenia dietetycznego i farmakologicznego. Pediatr Współcz Gastroenterol Hepatol Żyw Dz 2008; 10: 117-21.

32. Rotsztejn H, Kamer B, Raczyńska J, Pyziak K. Diagnostic difficulties in differentiation between atopic dermatitis and seborrheic dermatitis in infants. Pol Merk Lek 2005; 113: 678-80.

33. Hanifin JM, Rajka G. Diagnostic features of atopic dermatitis. Acta Dermatovener (Stockholm) 1980; 92 (Suppl.): 44-7.

34. Kamer B, Pasowska R, Rotsztejn H, et al. Coexistence of digestive tract symptoms in children with atopic dermatitis - based on own observations. Gastroenterol Pol 2010; 17: 401-4.

35. Kjellman NIM, Johansson SG, Roth A. Serum IgE levels in healthy children quantified by a sandwich technique (PRIST). Clin Allergy 1976; 6: 51-9.

36. Leung DY, Bieber T. Atopic dermatitis. Lancet 2003; 361: 151-60.

37. Isolauri E, Tahvanainen A, Peltola T, Arvola T. Breast-feeding of allergic infants. J Pediatr 1999; 134: 27-32.

38. Kaczmarski M, Cudowska B, Daniluk U, et al. The role of elimination diet in food hypersensitivity in children and adolescents. Acta Pneumonol Allergol Pediatr 2007; 10: 12-3. 